\title{
Scholars and Literati at the University of Heidelberg (1386-1800)
}

\author{
David de la Croix \\ Robert Stelter \\ IRES/LIDAM, UCLouvain \\ University of Basel
}

This note is a summary description of the set of scholars and literati who taught at the University of Heidelberg from its inception in 1386 to the eve of the Industrial Revolution (1800).

\section{The University}

Established in 1386, the Ruprecht Karls University in Heidelberg (Universitas Ruperto Carola Heidelbergensis) is the oldest university in Germany. It is located in one of the many States that belonged to the Holy Roman Empire: the (Electorate of the) Palatinate, headed by the Count Palatine. Approved by the Papal Bull from Pope Urban IV on 23 October 1385, the Ruperto Carola was the third full university in the Holy Roman Empire north of the Alps. The university owes its creation to a unique historical constellation (Hinz 1965 Hermans and Nelissen 2005): the commitment of Count Ruprecht I, the opportunity to acquire scholars from Paris after the schism between the Pope in Rome (supported by the Germanic States) and the Pope in Avignon (supported by France), and the need to unify a fissuring Palatinate. Located in a relatively small city, its fate was shaped by local developments: the university boomed in the second part of the sixteenth century (and second part of the nineteenth century), was middling for most of the remaining time and was formally closed for some years during the Thirty Years war. Over its long history, the university developed from a scholastic university in the late Middle-Ages to a Protestant university, and had another transition to a Catholic university at the end of the seventeenth century (Wolgast 1986). During the Catholic era, the Jesuits controlled the chairs linked to theology and philosophy (including math courses).

\section{SOURCES}

The history of the University of Heidelberg is well-documented. Drüll wrote a collection of four books that provide a detailed overview of the scholars of Heidelberg University. The volumes on the periods 1386-1651 (Drüll 2002), and 1652-1802 (Drüll 1991) correspond to our observation window and are used as the main sources of our data set. In addition to well-documented scholars, Drüll lists a range of obscure scholars from the early years about whom there is little information. We only added a few scholars from a variety of different sources - among them the Repertorium Academicum Germanicum (Schwinges and Hesse 2019) - to her data collection.

\section{SOME STATISTICS}

Table 1 displays some descriptive statistics. There are 1210 scholars. Up to 1618 , the fraction of persons with known birth year is rather low, reflecting the high share of obscure scholars. Due to this selection effect, the explanatory power of mean ages at death and appointment are limited. The Thirty Years war significantly reduced the number of scholars in 1618-1685, but the amount of information available improves significantly. Up to the end of the eighteenth century $96.1 \%$ of the birth years are known. Neither the mean age of appointment nor of death shows any clear increase in the last two centuries of our observation window. The same applies for life expectancy 


\begin{tabular}{|c|c|c|c|c|c|c|}
\hline \multicolumn{2}{|c|}{ Period } & \multirow{2}{*}{$\begin{array}{l}\text { nb. } \\
\text { obs }\end{array}$} & \multirow{2}{*}{$\begin{array}{l}\% \text { birth year } \\
\text { known }\end{array}$} & \multirow{2}{*}{$\begin{array}{l}\text { mean age } \\
\text { at appoint. }\end{array}$} & \multirow{2}{*}{$\begin{array}{c}\text { mean age } \\
\text { at death }\end{array}$} & \multirow{2}{*}{$\begin{array}{c}\text { life exp. } \\
\text { at } 30\end{array}$} \\
\hline Start & End & & & & & \\
\hline 1348 & 1449 & 320 & 7.8 & 35.2 & 66.1 & 67.4 \\
\hline 1450 & 1526 & 389 & 12.3 & 29.2 & 60.1 & 59.8 \\
\hline 1527 & 1617 & 194 & 53.6 & 33.3 & 58.4 & 57.6 \\
\hline 1618 & 1685 & 54 & 81.5 & 34 & 60.4 & 60.6 \\
\hline 1686 & 1733 & 98 & 93.9 & 36.5 & 61.3 & 59.5 \\
\hline 1734 & 1800 & 155 & 96.1 & 34.3 & 60.7 & 59.7 \\
\hline \multirow[t]{3}{*}{1200} & 1800 & 1210 & 38.2 & 34 & $60 . \overline{5}$ & $60.1^{-}$ \\
\hline & & $\%$ birth place & median distance & $\%$ with & $\%$ with & \\
\hline & & known & birth-institution & Wikipedia & Worldcat & \\
\hline 1348 & 1449 & 96.9 & 148 & 2.8 & 3.8 & \\
\hline 1450 & 1526 & 98.2 & 75 & 5.9 & 9.8 & \\
\hline 1527 & 1617 & 99.5 & 148 & 28.4 & 55.7 & \\
\hline 1618 & 1685 & 96.3 & 226 & 40.7 & 75.9 & \\
\hline 1686 & 1733 & 90.8 & 127 & 15.3 & 63.3 & \\
\hline 1734 & 1800 & 94.8 & 127 & 18.1 & 71 & \\
\hline 1000 & 1800 & $9 \overline{6} . \overline{9}$ & 115 & 12.6 & $\overline{3} 0 . \overline{7}$ & \\
\hline
\end{tabular}

Table 1: Summary statistics by period

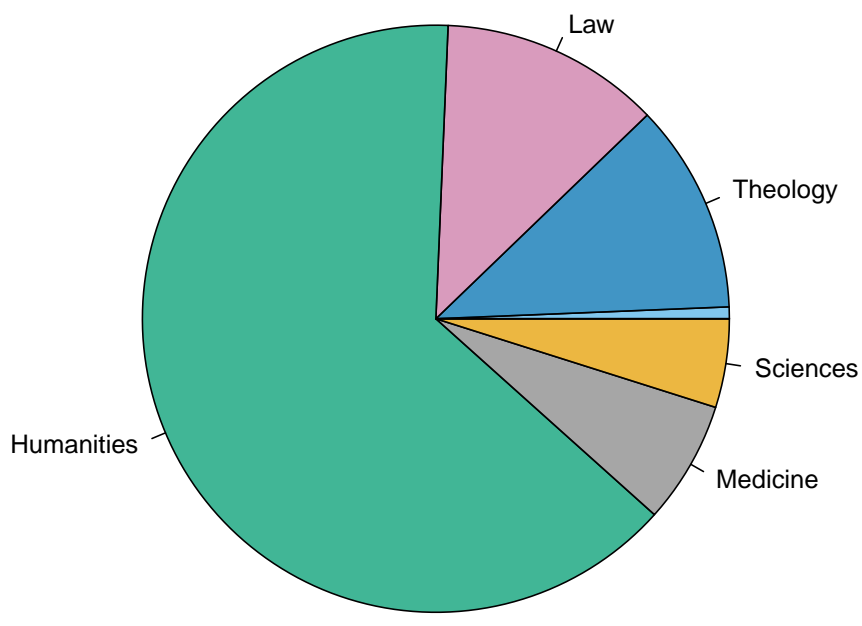

Figure 1: Broad fields at the University of Heidelberg 
(conditional on surviving to age 30). It remains at around 60 years and corresponds to the overall estimate for the Holy Roman Empire (Stelter, De la Croix, and Myrskylä (2021)).

We also observe the early selection in the birth years in the share of scholars who left a footprint either on Worldcat or Wikipedia. Initially, notable scholars are less than $10 \%$. While the share of scholars covered in Wikipedia improved to $40 \%$ in the seventeenth century, it fell back below $20 \%$ afterwards. By contrast, after the improvement in the share of scholars that left a footprint on Worldcat, it remains relatively high until 1800. The overall coverage on the place of birth is $96.9 \%$ and thus very high.

\section{FIELDS}

Figure 1. shows how the four traditional faculties dominated early modern full universities: the arts faculty, and the three higher faculties of law, theology, and medicine. The arts faculty was responsible for what we now consider to be humanities (philosophy, history, etc.) and sciences (mathematics, physics). With a share of about two-thirds, the field of humanities clearly dominates in Heidelberg.

\section{Place OF BIRTH}

Figure 2 is a plot of the places of birth of all the scholars active at the University of Heidelberg, per period. In the early years of the university, the majority of scholars were born around Heidelberg or in the Netherlands. A few scholars came from further away. In the period 1440-1527, distances declined; in particular scholars born in the Netherlands became rare. The mean and the variation in the distance increased with the rise of the Ruperto Carola in the second part of the 16th century. In 1527-1617, we observe a broadly scattered map of birth places. With the onset of the Thirty Years war, the place of origin of the scholars in Heidelberg was mainly limited to the German speaking territories and the share of long distances declined. The dominance of scholars from the GermanSpeaking area persisted after the end of the 17th century, when the university stagnated.

\section{HUMAN CAPITAL OF SCHOLARS AND LITERATI}

For each person in the database, we compute a heuristic human capital index, identified by combining information from Worldcat and Wikipedia using principal component analysis. We also compute the notability of the university at each date by averaging the human capital of the scholars active in Heidelberg 25 years before that date. Details are given in RETE in volumes 1-5. Figure 3 shows the names of all the scholars with a positive human capital index.

The orange line plots the notability of the university and clearly shows the mediocrity of the university until the fifteenth century. The subsequent boom ended with the Thirty Years War. The university did never fully recover from this shock over the period we consider.

\section{TOP 5 PROFESSORS}

We now provide a brief overview of the five professors with the highest human capital index.

Sebastian Münster (Nieder-Ingelheim 1488 - Basel 1552) was a well-known German cartographer, cosmographer and Christian Hebraist. The linguistically gifted Münster was trained by the Franciscan order, which he entered in 1505 in Strasbourg. Konrad Pelikan taught him at the Rouffach monastery, and he followed Pelikan to Basel in 1511. In the following years Münster taught at monastery schools, before Ludwig V appointed him as professor for Hebrew at the University of Heidelberg in 1524. His low salary - a fraction of what most other professors earned - forced him to increase his literary output (Burger 1952). In 1529, he left the Franciscan order to accept a position at the Lutheran University in Basel. During the CatholicLutheran conflicts he became Protestant. His publicatons at this time include his well-known Cosmographia. In 1552, he died of the plague. 

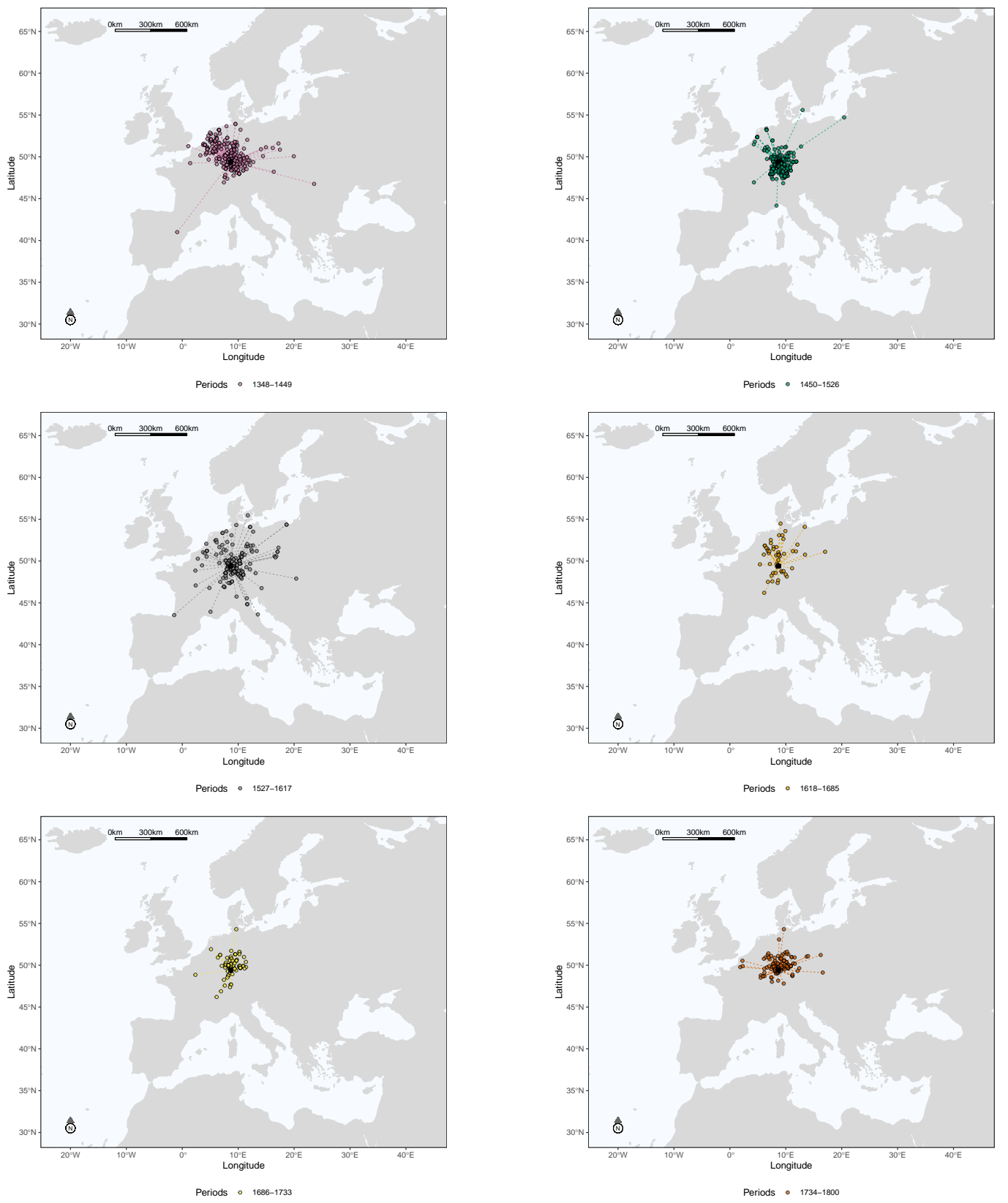

Figure 2: Places of birth of the scholars and literati at the University of Heidelberg 
Samuel Pufendorf (Zwönitz 1632 - Berlin 1694) was born as the fifth out of eight children and became an important political philosopher, economist, historian and the founder of the theory of natural law. After finishing his schooling at the Gymnasium St. Augustine as primus of the cohort, he started to study theology in Leipzig but soon switched to law. In 1656, he continued his studies in Jena where he was influenced by Erhard Weigel. He caught the attention of the Elector Palatine with the Elementa jurisprudentiae universalis libri duo, and he was granted the first chair of the law of nature and nations in the world. This position sat in the faculty of arts and not at the higher faculty of law (Luig 2003). His biting criticism of the imperial constitution triggered resentment among his colleagues and in 1670 Pufendorf left Heidelberg for Lund (see De la Croix (2021b) for further details on this period of his life).

Pierre de La Ramée (Cuts 1515 - Paris 1572) grew up in humble circumstances. The influential French humanist and philosopher studied in Paris and taught from 1551 at the Collège de France (see De la Croix (2021a)). Friedrich III aimed to advance the Ruperto Carola by appointing notable scholars, such as Ramée who was appointed extraordinary Professor of Ethics in 1569. The appointment failed due to the resistance at Heidelberg University, where the faculty prohibited his dialectic lectures. At the beginning of 1570, he moved back to Paris where he was killed in the Massacre of St. Bartholomew as a converted Protestant (Wolgast 1986).

Rudolf Agricola (Baflo 1444 - Heidelberg 1485) was a Dutch scholar and an important member of the Nordic early humanism movement. He studied in Erfurt, Cologne and Louvain, where he received his masters degree with highest honors in 1465 . He moved to Italy where he proceeded his studies in Pavia and Ferrara. In 1477, he rejected an offer for the Chair of Poetics in Louvain. Seven years later, he accepted the appointment to Heidelberg from Johann XX von Dalberg, Bishop from Worms, chancellor of the University of Heidelberg and an old friend he had met while studying in Pavia. In 1485, Agricola accompanied Dalberg, who was sent as an ambassador to Pope Innocent VIII to Rome. On his return journey Agricola fell ill and died in Heidelberg soon after his return (Kühlmann 1994). He was greatly respected by professors and students at the University, in particular for his approach to dialectic, submitting its concepts to a critical analysis through logic and reason.

Johann Brenz (Weil der Stadt 1499 - Stuttgart 1570) was a German theologian and Luther's reformer in the Duchy of Würtemberg. Educated at the University of Heidelberg, he was deeply impressed by Martin Luther's disputation there in 1518. In 1519, he started to teach Latin, Greek and Hebrew at the Faculty of Arts at the Ruperto Carola and became known for his interpretations of the Bible. Suspected of disseminating Luther's doctrines, he left Heidelberg in 1522 and became a clergyman at St. Michel in Schwäbisch Hall (Drüll 2002). He wrote important catechisms and was an opponent of witch-hunting.

\section{WHO'S WHO ON THE MOON}

Another way to measure the notability of individuals is to look for signs of recognition such as street names, names of schools, research institutes, prizes and lunar crater names. The following two professors received this honor, in recognition of their contribution to the advancement of sciences.

Michael Mästlin (Göppingen 1550 - Tübingen 1631) studied theology, mathematics and astronomy in Tübingen. In 1580, he became professor of mathematics in Heidelberg before moving to Tübingen in 1584. In 1961 a crater on the moon was named Mästlin in his honour. He is also well-known for one of his students, Johannes Kepler. 


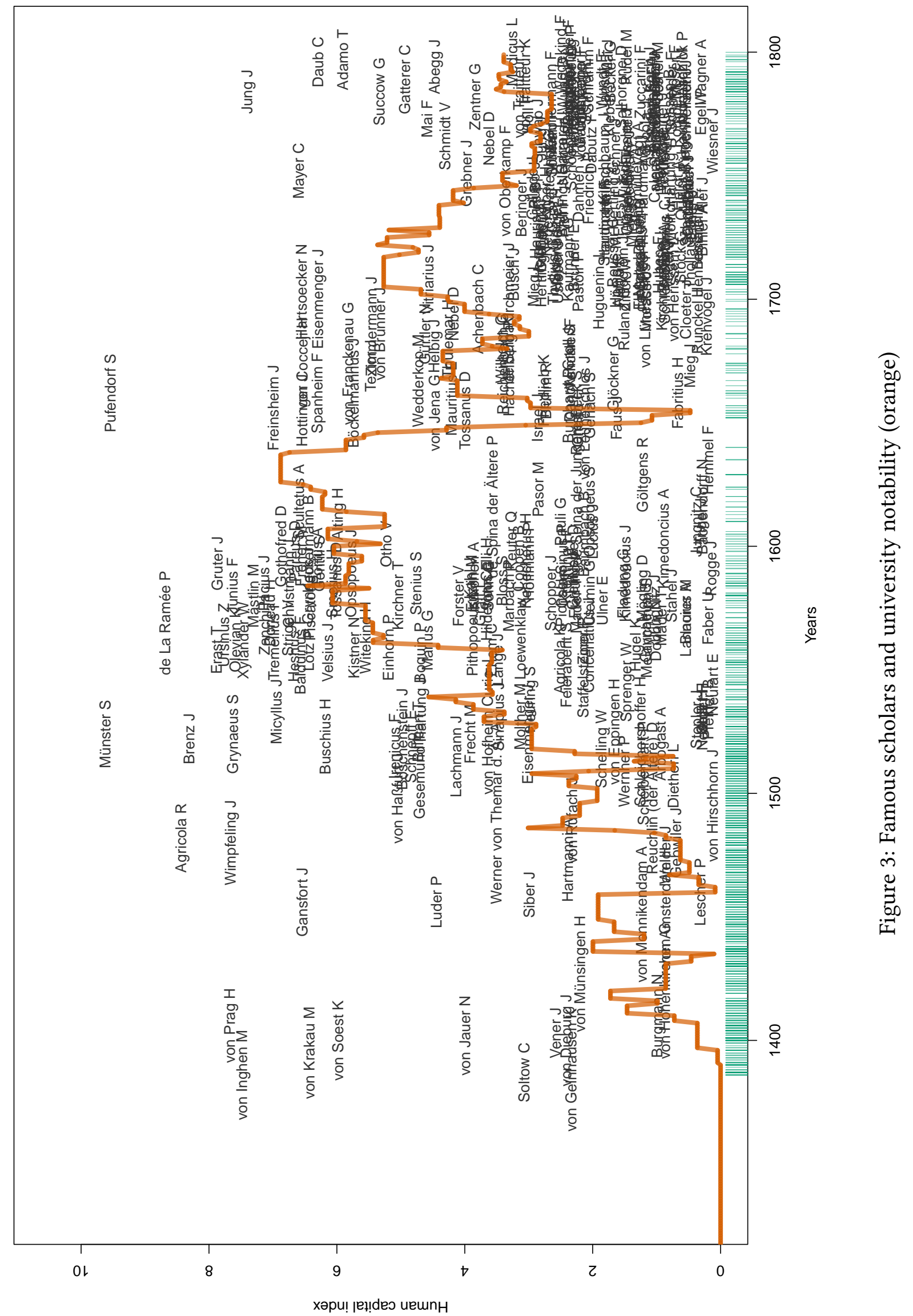


Christian Mayer (Mederitz 1719 - Mannheim 1783) was a German physician and meteorologist. He studied theology and joined the Jesuits. In 1751 he was appointed professor of philosophy in Heidelberg. One year later he moved to the chair of experimental physics at the same university. He joined several learned societies and has a moon crater named after him.

\section{FAMILIES OF SCHOLARS}

We counted 10 father-son pairs among the professors at the University of Heidelberg. Among them, there is the Nebel family. Figure 4 shows a fragment of the genealogical tree of the Nebel family, and highlights those who taught (law and medicine) at Heidelberg. Daniel Nebel (1558-1626) became full professor of law in Heidelberg in 1598 and elected rector of the university in 1603 and 1615. Daniel Nebel had, among others, a son Ludwig Daniel, who later became an electoral councilor in Heidelberg. This son was the father of the Palatinate court pharmacist Conrad Daniel Nebel (1632-1672). Daniel Nebel (1664-1733) was his son. Daniel was a professor of medicine, rector of the University, and was elected member of the Science Academy in Paris and of the Leopoldina. Wilhelm Bernhard (1699-1748) was his son, also a physicist, who took responsibility for the Heidelberg Botanical Garden, which his father had rebuilt in 1708. Finally, Daniel Wilhelm (1735-1805) was his son, who was appointed full professor of medicine and chemistry in 1771.

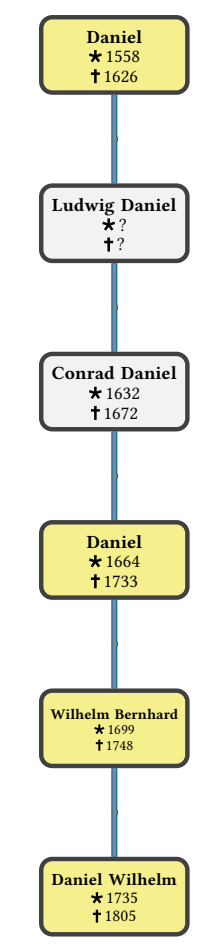

Figure 4: The Nebel family. Professors at Heidelberg in yellow squares

\section{UNIVERSITY NETWORK}

Here, we assume that when a professor occupied a position in more than one university over his/her life, this established a link between those universities. The universities with which Heidelberg was linked in each period are displayed in Figure 5

While the university network of the University of Heidelberg at the beginning included most of the surrounding universities, the link to Paris as the superior university at that time (De la Croix et al. 2020) played a particular role (Panel a). As early as in the fifteenth century, this link disappeared and was replaced by the growing universities around Heidelberg (Panel b). Still, during the boom of the university until the onset of the Thirty Years War, French and Dutch universities remained very 

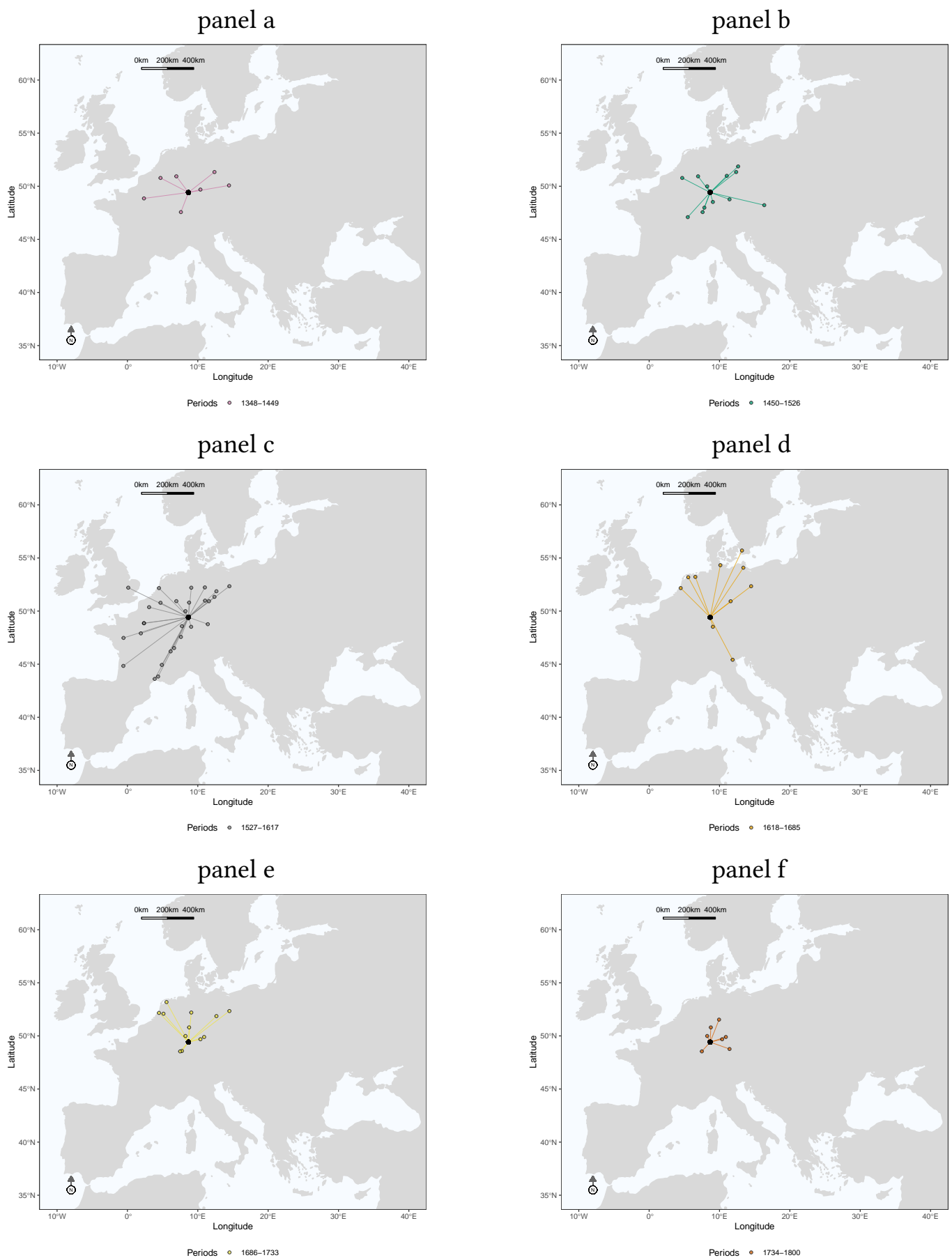

Figure 5: Links between Heidelberg and other universities through scholars' mobility, by period 
important (Panel c). Afterwards, we observe a dramatic shift from France to the evangelic areas in the North of Heidelberg (Panel d). This network extended further around the turn of the 18th century, but the extension started to decline. This trend persisted until the eighteenth century when the network fell back to the surrounding universities (Panel f) and thus shows some similarities to the mapping of birth places.

\section{ANECDOTES}

From the dream of a little Paris to the struggle of existence: The recruitment of very notable scholars during the foundation of the University of Heidelberg fostered the dream of a little German Paris in Heidelberg. These first generation of scholars attracted almost 600 enrollments in the year of establishment. The dream came to an abrupt end when plague and war dispersed scholars and students soon after. The establishment of nearby universities in Cologne and Erfurt with better preconditions, such as more donors, exacerbated the struggle. Presumably, the notable first generation of scholars did not manage to establish a German Paris, but they were sufficiently attractive to secure the survival of the university in the challenging early years (Wolgast 1986).

Money, Corn and a lot of wine: Up to the industrial revolution it was rather common to pay scholars' salaries in money and in kind. The latter often took the form of corn and wine. Friedrich Spanheim, a well-known theologian, received 160 guilder, about 18,000 litres of corn (18 Malter) and a cart load of wine (1 Fuder = 1000 liter) from the University of Heidelberg (Drüll 1991).

\section{ACKNOWLEDGMENTS}

This project has received funding from the European Research Council (ERC) under the European Union's Horizon 2020 research and innovation programme under grant agreement No 883033 "Did elite human capital trigger the rise of the West? Insights from a new database of European scholars." Robert Stelter acknowledges financial support from the Max Geldner Foundation.

First version January 20, 2022

\section{REFERENCES}

Burger, Alexander. 1952. Sebastian münsters lebenslauf. In Gedenkschrift zum 400. todestag von sebastian münster. Mainz: Druck O. Schneider.

De la Croix, David. 2021a. Scholars and Literati at the Royal College in Paris (1530-1800). Repertorium Eruditorum totius Europae 1:19-24. https://doi.org/10.14428/rete/v1i0/Royal-College.

. 2021b. Scholars and Literati at the University of Lund (1666-1800). Repertorium Eruditorum totius Europae 5:53-60. https://doi.org/10.14428/rete.v5i0/lund

De la Croix, David, Frédéric Docquier, Alice Fabre, and Robert Stelter. 2020. The Academic Market and the Rise of Universities in Medieval and Early Modern Europe (1000-1800). CEPR Discussion Paper 14509.

Drüll, Dagmar. 1991. Heidelberger gelehrtenlexikon: 1652-1802. Berlin, Heidelberg: Springer Berlin Heidelberg.

2002. Heidelberger gelehrtenlexikon 1386-1651. Berlin, Heidelberg: Springer Berlin Heidelberg / Imprint / Springer. https://doi.org/10.1007/978-3-642-56189-4.

Hermans, Jos MM, and Marc Nelissen. 2005. Charters of foundation and early documents of the universities of the Coimbra Group. Leuven: Leuven University Press.

Hinz, Gerhard. 1965. Die Ruprecht-Karl-Universität heidelberg. Bücherreihe von Universitäts Publikationen der Länderdienst AG. Basel: Länderdienst Verlag. 
Kühlmann, Wilhelm. 1994. Memoria. Bern: P. Lang.

Luig, Klaus. 2003. Pufendorf, samuel freiherr von. In Neue deutsche biographie 21. https://www. deutsche-biographie.de/pnd118597051.html.

Schwinges, Rainer Christoph, and Christian Hesse. 2019. Repertorium Academicum Germanicum. Https://en.rag-online.org/.

Stelter, Robert, David De la Croix, and Mikko Myrskylä. 2021. Leaders and Laggards in Life Expectancy among European Scholars from the Sixteenth to the Early Twentieth Century. Demography 58:111-135. https://doi.org/10.1215/00703370-8938107.

Wolgast, Eike. 1986. Sechshundert jahre universität heidelberg. In 600 jahre ruprecht-karls Universität heidelberg 1386-1986 : geschichte, forschung und lehre. Monographien über Universitäten und Hochschulen. München: Länderdienst Verlag. 